\title{
Flood maps in Europe - methods, availability and use
}

\author{
H. de Moel ${ }^{1}$, J. van Alphen ${ }^{2}$, and J. C. J. H. Aerts ${ }^{1}$ \\ ${ }^{1}$ Institute for Environmental Studies, Vrije Universiteit, Amsterdam, The Netherlands \\ ${ }^{2}$ Ministry of Transport, Public Works and Water Management, Lelystad, The Netherlands
}

Received: 8 October 2008 - Revised: 8 January 2009 - Accepted: 8 January 2009 - Published: 4 March 2009

\begin{abstract}
To support the transition from traditional flood defence strategies to a flood risk management approach at the basin scale in Europe, the EU has adopted a new Directive (2007/60/EC) at the end of 2007. One of the major tasks which member states must carry out in order to comply with this Directive is to map flood hazards and risks in their territory, which will form the basis of future flood risk management plans. This paper gives an overview of existing flood mapping practices in 29 countries in Europe and shows what maps are already available and how such maps are used. Roughly half of the countries considered have maps covering as good as their entire territory, and another third have maps covering significant parts of their territory. Only five countries have very limited or no flood maps available yet. Of the different flood maps distinguished, it appears that flood extent maps are the most commonly produced floods maps (in 23 countries), but flood depth maps are also regularly created (in seven countries). Very few countries have developed flood risk maps that include information on the consequences of flooding. The available flood maps are mostly developed by governmental organizations and primarily used for emergency planning, spatial planning, and awareness raising. In spatial planning, flood zones delimited on flood maps mainly serve as guidelines and are not binding. Even in the few countries (e.g. France, Poland) where there is a legal basis to regulate floodplain developments using flood zones, practical problems are often faced which reduce the mitigating effect of such binding legislation. Flood maps, also mainly extent maps, are also created by the insurance industry in $\mathrm{Eu}-$ rope and used to determine insurability, differentiate premiums, or to assess long-term financial solvency. Finally, flood maps are also produced by international river commissions. With respect to the EU Flood Directive, many countries al-
\end{abstract}

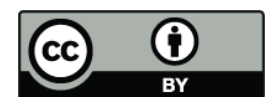

Correspondence to: H. de Moel (hans.de.moel@ivm.vu.nl) ready have a good starting point to map their flood hazards. A flood risk based map that includes consequences, however, has yet to be developed by most countries.

\section{Introduction}

River floods are considered one of the most important natural disasters in Europe (together with storms) and have caused about 100 billion euros of damage over the period 19862006 (CEA, 2007). Furthermore, it has now been widely accepted that the frequency and magnitude of river floods may increase because of climate change (Milly et al., 2002; Kundzewicz et al., 2007; Kleinen and Petschel-Held, 2007). These observations have initiated a flow of hydrological research that address projected changes in discharges and water levels under future climate conditions in European river systems such as the rivers Rhine, Elbe, and Danube (Middelkoop et al., 2001; Aerts et al., 2006; Dankers et al., 2007; Lucarini et al., 2008; te Linde et al., 2008). Such studies yield important insights into how flood indicators, such as the probability of extreme discharges, may change. Knowledge about these indicators is important for adequate design and development of flood management strategies that protect people against floods such as embankments.

During the last few decades, however, increased attention has been paid to the consequences of floods and measures that could be developed to reduce the effects of a flood. This has been triggered by the observation that economic and insured losses due to "extreme" floods have drastically increased during the last two decades (Munich RE, 2005) even though flood protection investments have also increased. The main explanation for this trend can be found in socioeconomic developments and spatial planning policies, as it appears that wealth and exposure have increased in flood-prone areas (Munich RE, 2005; EEA et al., 2008). Even in areas where the overall population growth is slowing down

Published by Copernicus Publications on behalf of the European Geosciences Union. 
(for example, along the Rhine river), population growth in cities along rivers tends to be increasing (see e.g. LDS NRW, 2008). Flood-prone areas remain attractive for socioeconomic activities and it is therefore likely that the damage potential (as in the amount of assets in flood-prone areas) will continue to increase in the future.

Recent research therefore suggests to follow a risk-based approach in flood management (Hooijer et al., 2004; Petrow et al., 2006; van Alphen and van Beek, 2006). The aim of such strategies is to reduce the overall flood risk, which is defined as the probability of an event multiplied by its consequences. This can be done through limiting the magnitude and probability of the flood (the hazard), the damage potential (exposure), and/or the way flood events are dealt with (coping capacity) (see definition by Kron, 2002). Some European countries have already recognised the need to adopt risk management approaches over the traditional flood protection strategies (e.g. Germany (DKKV, 2004), the Netherlands (Vis et al., 2003; Roos and Van der Geer, 2008), the UK (Tunstall et al., 2004)).

The necessity to move towards a risk based approach has also been recognised by the European Parliament, which adopted a new Flood Directive (2007/60/EC) on 23 October 2007. The objective of this directive is to establish a framework for the assessment and management of flood risk in Europe, emphasising both the frequency and magnitude of a flood as well as its consequences. There are different types of flooding, all resulting in an inundation of areas outside the watercourse. The EU directive addresses floods from rivers, from the sea, in ephemeral water courses, mountain torrents, and floods from sewage systems. The directive requires member states to draw up flood risk management plans by 2015. In preparation for this, a preliminary flood risk assessment is due by 2011, and flood hazard and risk maps need to be created by 2013 as they serve as essential tools in the preparation of management plans. As flood risk is not constant over time, these maps (as well as the plans) need to be revised every 6 years.

Flood mapping is thus an important aspect for EU member states in order to meet the requirements of the new Flood Directive. The mapping of flood hazards is not new, and numerous governments and private institutions have already mapped flood hazards for different purposes (van Alphen et al., 2008; de Moel and Aerts, 2008). The USA and Canada have initiated several national flood programs in which flood mapping is an important activity. In 1968 the National Flood Insurance Program (NFIP, see e.g. Burby, 2001) was launched in the USA and in 1976 the Flood Damage Reduction Program (FDRP, see e.g. Roy et al., 2003, or Watt, 2000) started in Canada. In Europe, most large-scale flood mapping activities were initiated during the late 1990s, triggered by large flooding events (e.g. Høydal et al., 2000).

The main goal of this paper is to provide an overview of existing flood maps in Europe and their underlying methodologies. This is a first step in assessing the status of flood risk mapping in Europe as required by the new flood Directive. The main focus is on the mapping of river floods and their associated hazards and risk. The remainder of the paper is organized as follows. Section 2 will describe different methodologies underlying flood maps and distinguish different types of flood maps. Section 3 describes what kinds of maps are produced by both European governments and the insurance industry, and how these maps are currently used ${ }^{1}$. In Sect. 4 conclusions are drawn and the link between current mapping activities and the EU Flood Directive is explored. Furthermore, suggestions and recommendations are made on how to proceed with flood risk mapping in Europe.

\section{Assessing and mapping flood hazard and risk}

In the field of flood risk management there is a sometimes confusing use of terms, with especially risk and vulnerability having different meanings. Efforts have been made by several authors to better define risk and related terms (e.g. Kron, 2002; Samuels and Gouldby, 2005; Merz et al., 2007). All these definitions agree that risk is a combination of the physical characteristics of the flood event (the hazard) and its potential consequences. We distinguish "exposure" and "coping capacity" as two elements making up the potential consequences. With exposure signifying what can be affected by a flood (buildings, land use, population), and coping capacity relating to how the adverse effects of a flood can be dealt with (being influenced by: preparedness, precautionary measures, insurance, health (sick, elderly), financial situation, etc.). This is mostly in line with other definitions (like Kron, 2002; Samuels and Gouldby, 2005; Merz et al., 2007) but avoids the use of the term "vulnerability", which is used very unambiguously (see Samuels and Gouldby, 2005).

Similarly to risk related definitions, some confusion can arise in the naming of different flood maps. While the classification presented here is broadly consistent with Merz et al. (2007), we extended the amount of types in order to cover the full range of different flood map types identified in this study (Sect. 2.2). As a result, mainly the term flood danger map is used differently here and, as mentioned, we do not use the term vulnerability.

Flood maps exist in many different forms, but in general it is possible to distinguish between flood hazard and flood risk maps. Flood hazard maps contain information about the probability and/or magnitude of an event whereas flood risk maps contain additional information about the consequences (e.g. economic damage, number of people affected). Within these two general types, however, there are different methods available to quantify hazards and risks, resulting in different types of flood maps (Fig. 1). The general

\footnotetext{
${ }^{1}$ This paper is based on the information available to the authors at the time of writing. It should not be considered completely comprehensive and does not aim to judge or grade the mapping activities of European countries.
} 


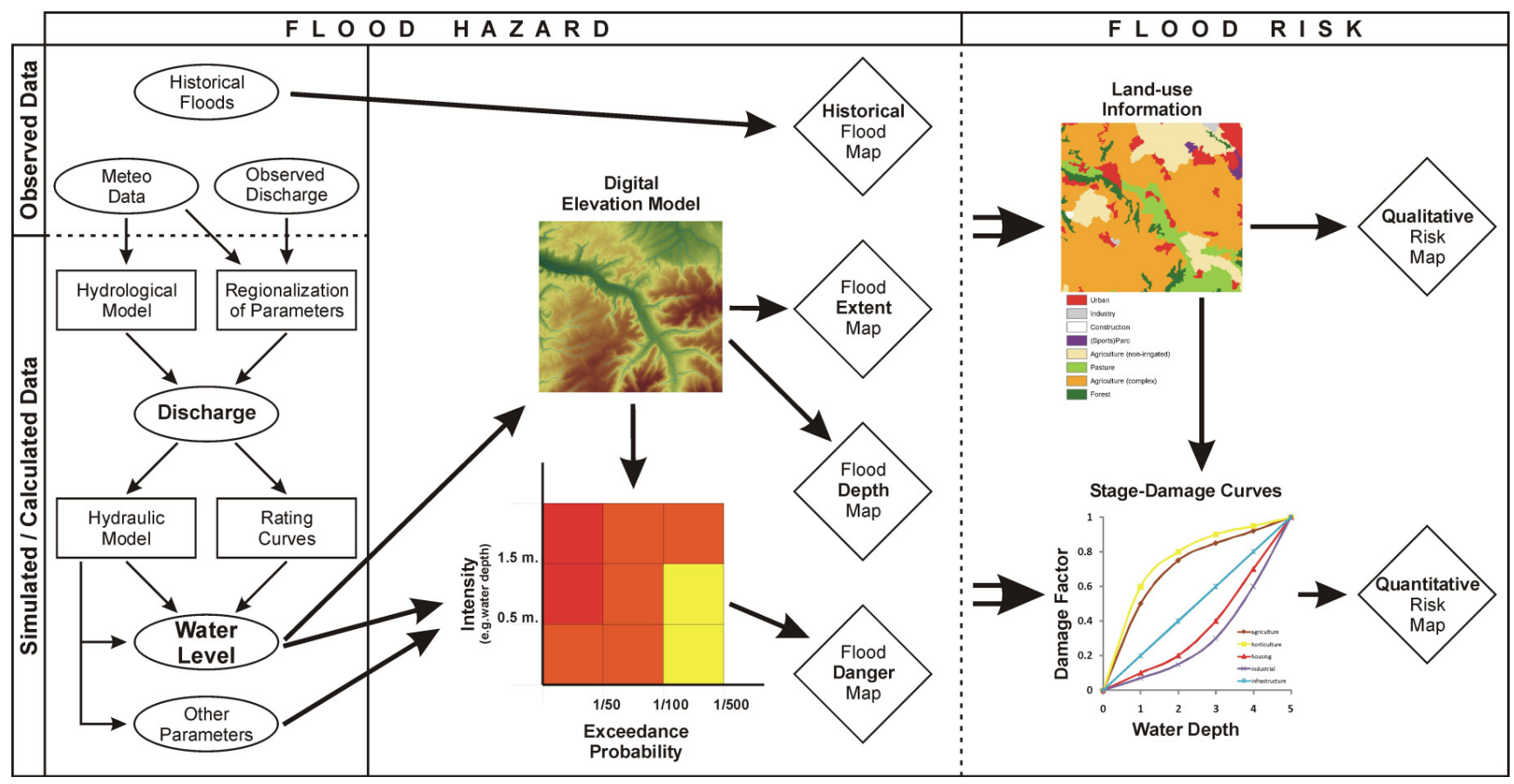

Fig. 1. Conceptual framework for flood hazard and risk calculations. The displayed matrix and curves are purely illustrative and based on a hypothetical case. In the matrix the yellow colour signifies low danger, the orange colour moderate danger and the red colour high danger.

methodology (Sect. 2.1), as well as different types of floods maps (Sect. 2.2), will be discussed below. The practices of some European countries will be used as examples. References to the information sources concerning these practices can be found in Table 1 .

\subsection{Assessing flood hazard}

When assessing the flood hazard, a first indication can be obtained by looking at how often floods occurred historically and the magnitude of them. These can be mapped as point events (as in Ireland, similar to Fig. 2a), or extents of historical floods can be depicted on a flood extent map (like Fig. 2b). With the advent of remote sensing imagery, flood extents of current (or very recent) floods can easily and accurately be determined. This opens up possibilities to calibrate or validate flood extents simulated by computer models. To create and implement policy with respect to flood management it is important to have up to date flood information which is consistent over the entire territory. The use of historical flood maps is in this respect restricted since it is impossible to compare them as return periods are not equal and boundary conditions (streambed, land cover, etc.) may have changed significantly over time.

To overcome this problem, statistical and modelling tools are used to calculate the hazard of hypothetical floods. There are various parameters that can be used to denote the flood hazard. These include the flood extent, water depth, flow ve- locity, duration, propagation of water front, and the rate at which the water rises. Water depth is one of the main factors of importance with respect to flood damage. However, in steep upstream areas and next to dike-breach locations flow velocity (and debris content) is a very important factor for flood damage. In polder areas the duration of inundation can be so long that it becomes an important factor for the resulting damage, for instance because of costs associated with emergency housing, business interruption, and the collapse of supply chains. Furthermore, information on the propagation of the flood wave and the rate at which the water rises is critical for emergency planners in charge of evacuation, and to estimate the potential loss of life (Jonkman, 2007).

The calculation of the flood hazard can be done using methods of varying complexity (Buchele et al., 2006), depending on the amount of data, resources, and time available. While there are different approaches the conceptual framework behind the calculation of flood hazards is quite general (Fig. 1) and consists broadly of three steps:

1. The first step is to estimate discharges for specific return periods. This can be done by using frequency analyses on discharge records and fitting extreme value distributions (e.g. te Linde et al., 2008). When there is no discharge data available but there are precipitation records, runoff coefficients can be used (as done in Austria, see Merz et al., 2008) to deduce discharge information. Whether direct discharge measurements or discharge information derived from precipitation records 
are used, only a fraction of the basin is usually gauged, whilst for national flood mapping projects information is required for all river stretches. To overcome this, flood information (e.g. discharge, precipitation, or flood moments) can be extrapolated to ungauged parts using regionalisation techniques (see e.g. Merz and Bloschl, 2005). More often however, hydrological models are used to calculate discharges. Such models come in various complexities (e.g. Hurkmans et al., 2008), but they all require spatially explicit meteorological (e.g. temperature, precipitation, evaporation, radiation), soil, and land cover data as input. This data can be acquired from datasets of interpolated observed data, from re-analysis datasets (e.g. the ECMWF ERA datasets), or from climate models (e.g. the Hadley and ECHAM models). Spatial hydrological models solve the water balance for each geographical unit (e.g. grid-cell) for each time step and route the runoff downstream, yielding discharges throughout the entire catchment. Such models can additionally be used in scenario analysis, for example in the assessment of the impact of changes in climate or land cover by changing the input meteorological data or land cover scheme.

2. When discharges and their return periods have been derived using the above mentioned approaches, a subsequent step towards developing a flood map is to translate discharges into water levels. This is usually done with rating (stage-discharge) curves. Alternatively, 1D or 2-D hydrodynamic models can be used to determine water levels. The latter is especially useful in hydraulically complex areas like river confluences, polders, or drainage systems that have been heavily modified through human interference. Furthermore, hydrodynamic models allow for considering additional flood parameters, like flow velocity, propagation, duration, and the rate at which the water rises. Some additional information is however required for 2-D hydrodynamic modelling, like flood wave characteristics (duration, peak).

3. In the third step the flooded area (and possibly flood depth) is determined by combining water levels with a digital elevation model (DEM), thus creating a flood map showing flood extent or depth. A DEM is already included in 2-D hydrodynamic models, in which case this third step is already addressed.

As with all methods that use a wide range of data, calculations, and/or models, uncertainties in the data and processing steps accumulate in the final output. Major sources of uncertainty with respect to flood hazard mapping include the statistical determination of extreme events from relatively short time series, the spatial extrapolation of data (when used), the DEM, and the presence and/or failure of defence structures. With respect to the DEM, there has been a huge improvement in spatial resolution over the last few decades. However, the resolution is still usually too low for distinguishing levees or flood walls correctly, especially when working at a national scale. When a high resolution DEM is used, the presence of viaducts or other line structures above ground can wrongly be interpreted as flood barriers, whilst in reality they do not stop the water at all. Sometimes flood defences are added as separate line elements, but in such instances the assumption is usually made that the defences will not fail. This assumption becomes increasingly uncertain with higher design standards for flood works. Therefore the proper schematisation of these elements requires thorough field surveys and the expertise of local flood and water managers.

\subsection{Flood map types}

\subsubsection{Flood extent maps}

The most common flood hazard maps are flood extent maps (Fig. 2b). These are maps displaying the inundated areas of a specific event. This can be a historical event, but also a hypothetical event with a specific return period (e.g. once every 100 years, often expressed as $\mathrm{HQ}_{100}$ ). The extent of a single flood event, or of multiple events, can be depicted and also the extent of historical floods can be shown. As flood extents are easy to depict they can be supplemented with point information on other flood parameters (e.g. depth or velocity at some points) and important exposed assets (e.g. hospitals, power stations).

\subsubsection{Flood depth maps}

When flood extents are calculated for specific return periods, flood depths can also easily be calculated. Depicting these water depths on a separate map results in a flood depth map (Fig. 2c). A different type of water depth map is created in areas where flooding is not the result of overtopping but rather of failing structures (e.g. polder areas). In such cases it is not possible to calculate general flood extents and depth for a specific return period as the flooded area is determined by the location of a breach, which is not known beforehand, and scenarios are often used. In order to generate a general picture of the flood hazard, the results of these scenarios can be combined into a single map showing the maximum (or average) flood depth per pixel (as is done in the Netherlands for example).

\subsubsection{Maps displaying other flood parameters}

Flood extents and depths are usually considered the most important flood parameters, especially when it comes to mapping flood hazards. However, some other parameters, such as velocity, duration, propagation, and the rate of rising of the water, can also be very important depending on the situation and the purpose of the map. In Flanders, for instance, there are maps showing the rate at which the water rises, in Austria and Luxembourg the flow velocity is mapped, and 


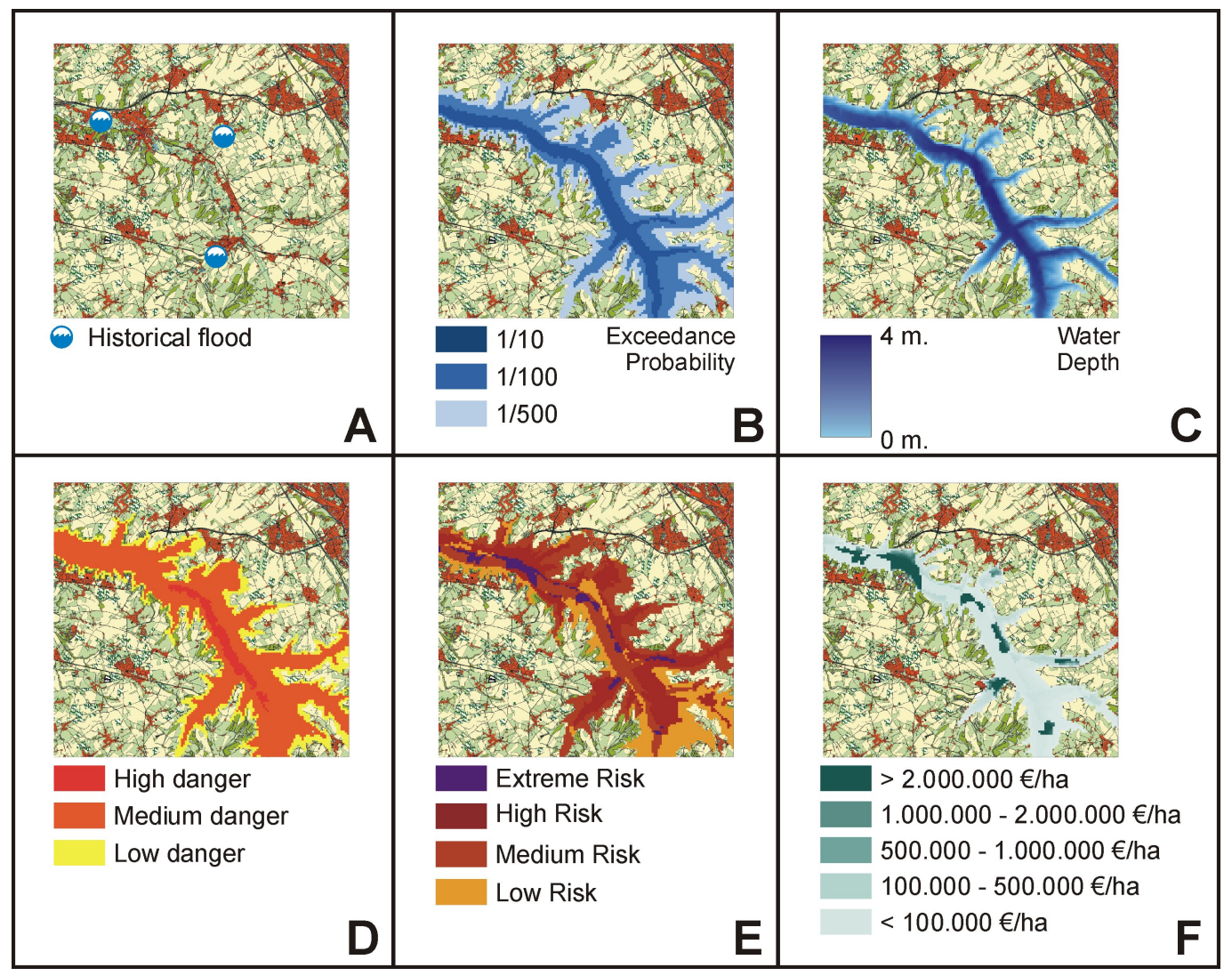

Fig. 2. Different flood map types. (A) historical flood map; (B) flood extent map; (C) flood depth map; (D) flood danger map; (E) qualitative risk map; (F) quantitative risk (damage) map. The displayed maps are purely illustrative and based on a hypothetical case.

in Hungary and the Netherlands propagation maps of flooding polders will be created for the entire territory in the near future. Maps showing such parameters always relate to a single return period, as it is practically impossible to depict, for instance, velocities of several return periods on a single map.

\subsubsection{Flood danger maps}

Flood maps usually only show one out of several flood parameters, though in some cases flood depth information of a specific return period is added to a flood extent map (e.g. Austria, Saxony). In order to get an impression of the overall flood hazard, parameters can instead be aggregated into qualitative classes, resulting in a so-called flood danger map (Fig. 2d). This is commonly done using matrices or formulas to relate different flood parameters into a single measure for the "danger". In such matrices (see Fig. 1), two axes are used to relate flood parameters (e.g. depth, velocity, return period), or sometimes a grouped parameter is used (e.g. "intensity" as used in Rheinland-Pfalz is a combination of water depth and flow velocity (van Alphen and Passchier, 2007)), into qualitative danger categories (e.g. Switzerland, Wallonia, Rheinland-Pfalz). An example of the use of a formula to calculate a measure for the flood danger can be found in the UK, where the hazard rating is defined as: depth $\times($ velocity +0.5$)+$ debris factor (van Alphen and Passchier, 2007).

\subsubsection{Exposure and coping capacity}

In flood risk management not only is information on the flood hazard desirable, but also information on the consequences of a flood. The consequences of a flood depend broadly on the damage potential and the coping capacity of a region to handle a flood. As there are countless consequences there are also many different indicators. Indicators for coping capacity (health, financial situation) are often especially difficult to quantify and are therefore usually disregarded in risk assessments (though in the UK a coping capacity map has been created). The potential damage of a flood on houses, industry, infrastructure, agriculture, etc. (exposure) is easier to assess. However, particular types of damage, such as cultural damage, ecological damage, and indirect damage (e.g. due to business disruption), are still very difficult to quantify. When such indicators are considered this is usually done in a qualitative way, resulting in indices or ratios (e.g. Italy, Spain). 


\subsubsection{Flood risk maps}

When information on the consequences of a flood is combined with the hazard information, risk maps can be created. As most indicators for exposure and coping capacity are qualitative, this results in qualitative risk maps (Fig. 2e). The main quantifiable indicator for exposure is direct economic damage. A common method to calculate direct damage is by using stage-damage functions (see Fig. 1), which represent the relationship between inundation depth (and/or some other flood parameter) and the resulting damage of an object or land-use type. This yields the potential damage of an event (Fig. 2e) or even the expected damage per area per year (e.g. Flanders). Stage-damage functions are either based on empirical data from past flood events (e.g. HOWAS database in Germany) or are synthetically created by experts. The use of stage-damage functions, however, still involves considerable uncertainty (Merz et al., 2004), and absolute damage figures should be interpreted with caution. Furthermore, the direct financial damage estimated in this way is only part of the total damage (see e.g. Jonkman et al., 2003). Indirect financial damage is usually not included (or only very roughly estimated) in flood damage estimations and non-monetary damage is usually excluded altogether.

As a result of the wide range of flood indicators available (for both hazard and consequence), many different types of flood maps exist. These are often not comparable (especially in the case of qualitative ones) since they are based on different approaches. In particular, flood risk maps should not be considered as homogeneous as flood hazard maps (like flood extent or depth) because of the many indicators that are available for the consequence of a flood compared to the relative few indicators for the flood hazard. In many cases the indicators used and the type of flood risk map created depends on the question that needs to be addressed. For example, insurers use insured damage, for evacuation planning population density is important, etc.

\subsection{European Flood Directive requirements}

In order to comply with the European Flood Directive [2007/60/EC] member states are currently obliged to create both flood hazard and flood risk maps. Flood hazard maps should cover areas that may be affected by floods with a low probability (extreme event), floods with a medium probability (return period $\geq 100$ years) and, where appropriate, floods with a high probability $\left(\sim \mathrm{HQ}_{10}\right)$. Principally, the directive requires member states to create flood extent maps for the above return periods. Member states are encouraged to depict flood depth and flow velocity information as well when appropriate. The flood risk maps required by the directive are qualitative risk maps which should show the number of potentially affected inhabitants, the types of economic activity, protected areas affected, and information on possible pollution sources.

\section{Availability and application of flood maps}

Flood maps are created by various institutions for various purposes. At the European scale, some flood maps have been produced providing a rather general indication of flood hazards and risks (Lavalle et al., 2005; Schmidt-Thomé et al., 2006). The most important producers of nation/basin wide maps are governmental institutions, the insurance industry, and transboundary river basin authorities (e.g. Rhine, Elbe, Danube basin authorities). Their mapping efforts in Europe will be described in the following sections.

\subsection{Governments}

Various surveys and reports provide information about the availability and use of flood maps in European Countries. A survey from the European Union ${ }^{2}$ and a survey leading up to the 2005 World Conference on Disaster Reduction in Kobe ${ }^{3}$ on hazard mapping and management both contain valuable information from different countries with respect to flood mapping practices and application. In addition, the Joint Research Centre of the EU has carried out a survey on flood hazard maps across 10 new member states and candidate countries in 2003/2004, the replies of which are summarised in Jelinek et al. (2007). Furthermore, the ARMONIA project has produced a report on spatial planning and natural risk management in eight European countries, including information on hazard and risk mapping and the use of such maps (ARMONIA, 2005). In addition, the European exchange circle on flood mapping (EXCIMAP) has compiled a handbook and atlas on flood mapping in Europe, containing examples from 19 European countries (EXCIMAP, 2007). The information from these and other sources is combined in Table 1, summarising the availability, types and use of flood maps in European countries.

\subsubsection{Availability of flood maps}

Almost all European countries have some flood maps available. Only Cyprus and Bulgaria do not seem to have any maps available, though Bulgaria does have maps related to dam failures. A couple of countries (Croatia, Denmark and Latvia) have maps for only very small parts of their territory. Out of the 29 countries considered, 14 have already mapped almost their entire territory with respect to flood hazards. In 10 countries a significant part, but not the entire territory, has already been mapped. This is usually because the mapping is still in progress or has purposefully been restricted to the most important areas (e.g. Norway, Sweden). In many cases the responsibility of mapping has been passed down to regional governments (provinces, Bundesländer, regional water authorities), like in Spain, Italy, Germany, Poland, and

\footnotetext{
${ }^{2} \mathrm{http} / / /$ ec.europa.eu/environment/civil/prote/hazard_mapping/

${ }^{3} \mathrm{http}: / /$ www.unisdr.org/wcdr/preparatory-process/ national-reports.htm
} 
Table 1. Overview of the availability and use of flood maps in European countries. As Cyprus and Bulgaria do not have national flood maps they have been omitted from the table. Belgium (BE) has been split in Flanders and Wallonia.

\begin{tabular}{|c|c|c|c|c|c|c|c|c|c|c|c|c|c|c|c|c|c|c|c|c|c|c|}
\hline \multirow{2}{*}{\multicolumn{2}{|c|}{ Country }} & \multicolumn{2}{|c|}{ Various } & \multicolumn{8}{|c|}{ Flood map type ${ }^{* * *}$} & \multicolumn{4}{|c|}{ Characteristics } & \multicolumn{7}{|c|}{ Use by government } \\
\hline & & 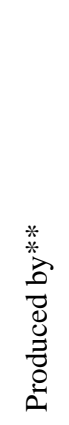 & 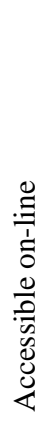 & 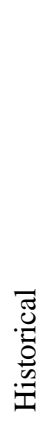 & 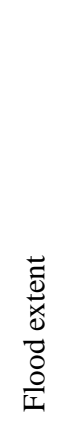 & $\begin{array}{l}\bar{\Xi} \\
\frac{0}{0} \\
\overline{0} \\
\frac{0}{I}\end{array}$ & 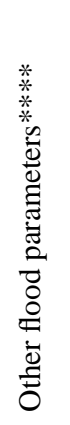 & 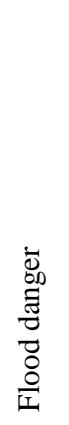 & 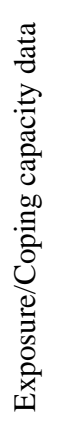 & 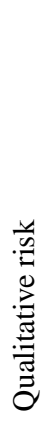 & 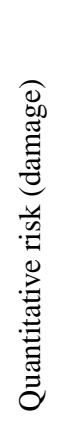 & 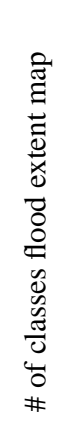 & 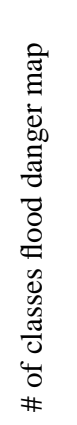 & 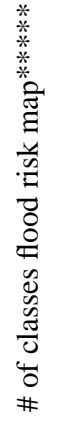 & 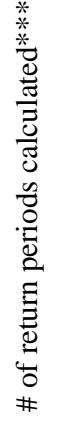 & 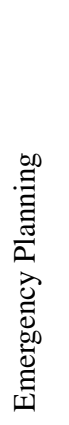 & 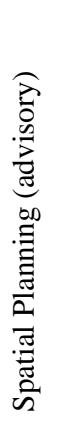 & 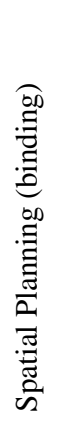 & 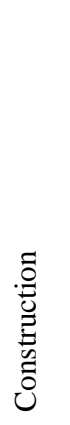 & 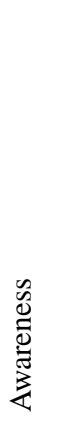 & 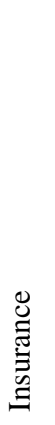 & 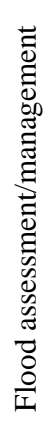 \\
\hline Flanders $(\mathrm{BE})^{\mathrm{a}, \mathrm{e}}$ & 1 & $\mathrm{R}$ & $\mathrm{Y}$ & $\mathrm{X}$ & $\mathrm{X}$ & $\mathrm{X}$ & $\mathrm{R}$ & & & & $\mathrm{X}$ & & & $\mathrm{C}$ & 17 & & & & & & $\mathrm{X}$ & $\mathrm{X}$ \\
\hline France $^{\mathrm{a}, \mathrm{f}}$ & 1 & $\mathrm{R}$ & $\mathrm{Y}$ & $\mathrm{X}$ & $\mathrm{X}$ & & & & $\mathrm{X}$ & $\mathrm{X}$ & & 1 & & 3 & 1 & & & $\mathrm{X}$ & $\mathrm{X}$ & $\mathrm{X}$ & & \\
\hline Switzerland ${ }^{\mathrm{a}, \mathrm{g}}$ & 1 & $\mathrm{R}$ & $\mathrm{y}$ & & $\mathrm{X}$ & $\mathrm{X}$ & & $\mathrm{X}$ & & $\mathrm{X}$ & & 1 & 4 & $\mathrm{~V}$ & 4 & $\mathrm{X}$ & & $\mathrm{X}$ & $\mathrm{X}$ & & & \\
\hline Netherlands $\mathrm{s}^{\mathrm{a}}$ & 1 & $\mathrm{C}$ & $\mathrm{Y}$ & & & $\mathrm{X}$ &. $\mathrm{V}$ & & . & . & . & & & & & $\mathrm{X}$ & & & & $\mathrm{X}$ & & $\mathrm{X}$ \\
\hline Great Britain ${ }^{\mathrm{a}, \mathrm{h}}$ & 1 & $\mathrm{C}$ & $\mathrm{Y}$ & & $\mathrm{X}$ & & & $\mathrm{X}$ & $\mathrm{X}$ & & & 2 & $4-7$ & & 4 & & $\mathrm{X}$ & & & $\mathrm{X}$ & $\mathrm{X}$ & \\
\hline Romania $^{\mathrm{b}, \mathrm{c}, \mathrm{d}}$ & 1 & $\mathrm{C}$ & & & $\mathrm{X}$ & & & & $\mathrm{X}$ & & & & & & $S$ & $\mathrm{X}$ & & $\mathrm{X}$ & & $\mathrm{X}$ & & \\
\hline Slovakia ${ }^{\mathrm{c}, \mathrm{d}}$ & 1 & $\mathrm{C}$ & & & $\mathrm{X}$ & & & & $\mathrm{X}$ & & & & & & $S$ & $\mathrm{X}$ & & & & & & $\mathrm{X}$ \\
\hline Wallonia $(\mathrm{BE})^{\mathrm{a}}$ & 1 & $\mathrm{R}$ & $\mathrm{Y}$ & & - & - & & $\mathrm{X}$ & & & & & 3 & & 3 & & & & & & & \\
\hline Hungary ${ }^{a, b}$ & 1 & & & & $\mathrm{X}$ & . &.$P$ & & & & & 2 & & & 2 & $\mathrm{X}$ & $\mathrm{X}$ & & & $\mathrm{X}$ & & \\
\hline Ireland $^{\mathrm{a}, \mathrm{c}}$ & 1 & $\mathrm{C}$ & $\mathrm{Y}$ & $\mathrm{X}$ & $\mathrm{X}$ & . & . & & & & & 3 & & & & & $\mathrm{X}$ & & & $\mathrm{X}$ & & $\mathrm{X}$ \\
\hline Lithuania $^{\mathrm{a}}$ & 1 & $\mathrm{R}$ & & $\mathrm{X}$ & $\mathrm{X}$ & & & & & & & & & & & $\mathrm{X}$ & & $\mathrm{X}$ & & & & \\
\hline Czech Rep. ${ }^{\mathrm{a}}$ & 1 & $\mathrm{R}$ & $\mathrm{Y}$ & $\mathrm{X}$ & $\mathrm{X}$ & & & & & & & 3 & & & 3 & $\mathrm{X}$ & & & & $\mathrm{X}$ & & \\
\hline Slovenia ${ }^{\mathrm{c}, \mathrm{d}}$ & 1 & $\mathrm{C}$ & & & $\mathrm{X}$ & & & & & & & & & & 4 & $\mathrm{X}$ & & & & & & \\
\hline Estonia $^{\mathrm{a}}$ & 1 & $\mathrm{C}$ & & $\mathrm{X}$ & & & & & & & & & & & & & & & & & & \\
\hline Greece $^{\mathrm{d}}$ & 1 & $\mathrm{C}$ & & $\mathrm{X}$ & & & & & & & & & & & & & & & & & & \\
\hline Germany ${ }^{\mathrm{a}, \mathrm{i}}$ & 2 & $\mathrm{R}$ & $\mathrm{y}$ & & $\mathrm{X}$ & $\mathrm{X}$ & & $\mathrm{X}$ & & & $\mathrm{X}$ & $1-4$ & 4 & $\sim 7$ & V & & & $\mathrm{X}$ & $\mathrm{X}$ & $\mathrm{X}$ & & \\
\hline Spain $^{a, j}$ & 2 & $\mathrm{R}$ & & $\mathrm{x}$ & $\mathrm{X}$ & & & & $\mathrm{X}$ & $\mathrm{X}$ & & 3 & & 5 & 3 & $\mathrm{X}$ & & $\mathrm{X}$ & & & & \\
\hline Italy ${ }^{\mathrm{a}, \mathrm{k}, \mathrm{l}}$ & 2 & $\mathrm{R}$ & $\mathrm{y}$ & & $\mathrm{X}$ & & & & $\mathrm{X}$ & $\mathrm{X}$ & & 3 & & 4 & 3 & & & $\mathrm{X}$ & & & & \\
\hline Finland $^{\mathrm{m}}$ & 2 & $\mathrm{R}$ & $\mathrm{y}$ & $\mathrm{X}$ & & $\mathrm{X}$ & & & - & & & & 5 & & & $\mathrm{X}$ & $\mathrm{X}$ & & $\mathrm{X}$ & $\mathrm{X}$ & & $\mathrm{X}$ \\
\hline Austria $^{\mathrm{a}, \mathrm{n}}$ & 2 & $\mathrm{C}$ & & & $\mathrm{X}$ & - & $\mathrm{V}$ & $\mathrm{X}$ & & & & 3 & 5 & & 3 & & $\mathrm{X}$ & & & & & \\
\hline Luxembourga,o & 2 & $\mathrm{P}$ & $\mathrm{Y}$ & & $\mathrm{X}$ & $\mathrm{X}$ & $\mathrm{V}$ & $\mathrm{X}$ & & & & 4 & 4 & & 4 & & $\mathrm{X}$ & & & $\mathrm{X}$ & & \\
\hline Poland ${ }^{a, p}$ & 2 & $\mathrm{R}$ & & & $\mathrm{X}$ & $X$ & & & & & & $2-8$ & & & V & $\mathrm{X}$ & & $X$ & & & & \\
\hline Norway ${ }^{a, q}$ & 2 & $\mathrm{C}$ & & & $\mathrm{X}$ & & & & & & & 1 & & & 6 & $\mathrm{X}$ & $\mathrm{X}$ & & & & & \\
\hline Portugal $^{\mathrm{c}, \mathrm{d}}$ & 2 & $\mathrm{~L}$ & & & $\mathrm{X}$ & & & & & & & & & & & $\mathrm{X}$ & $\mathrm{X}$ & & & $\mathrm{X}$ & & $\mathrm{X}$ \\
\hline Sweden ${ }^{\mathrm{a}, \mathrm{c}}$ & 2 & $\mathrm{C}$ & $\mathrm{Y}$ & & $\mathrm{X}$ & & & & - & & & 2 & & & 2 & $\mathrm{X}$ & $\mathrm{X}$ & & & & & $\mathrm{X}$ \\
\hline Croatia $^{a}$ & 3 & & & & $\mathrm{X}$ & & & & $\mathrm{X}$ & & $\mathrm{X}$ & 1 & & & 6 & & & & & & & \\
\hline Denmark $^{\mathrm{a}}$ & 3 & $\mathrm{C}$ & & & $\mathrm{X}$ & & & & & & & 1 & & & 2 & & & & & & & \\
\hline Latvia $^{\mathrm{a}}$ & 3 & $\mathrm{C}$ & & & $\mathrm{X}$ & & & & & & & 1 & & & V & $X$ & $\mathrm{X}$ & & & & & \\
\hline
\end{tabular}

* 1: (almost) entire territory; 2: some regions/ongoing; 3: limited areas/on request. ** $\mathrm{C}$ : central government; $\mathrm{R}$ : regional government; L: local government; P: project. *** - : information used in background of hazard map; . : will be developed. **** R: rate of rise; V: velocity; $\mathrm{P}$ : propagation. $* * * * * \mathrm{C}$ : continuous scale; $\mathrm{V}$ : varies depending on region. $* * * * * * \mathrm{~S}$ : several, exact amount not known but more then one; $\mathrm{V}$ : varies, depending on region/request.

a Van Alphen and Passchier (2007); bJelinek et al. (2007); c EU survey (2004); d National Report Kobe Conference (2005); e D'Haeseleer et al. (2006); ${ }^{\mathrm{f}}$ Fleischhauer (2005); ${ }^{\mathrm{g}}$ Zimmerman et al. (2005); ${ }^{\mathrm{h}}$ Fay and Walker (2005); ${ }^{\mathrm{i}}$ Greiving (2005); ${ }^{\mathrm{j}}$ Cantos (2005); ${ }^{\mathrm{k}}$ Galderisi and Stanganelli (2005); ${ }^{1}$ Menoni (2005); ${ }^{\mathrm{m}}$ Dubrovin et al. (2006); ${ }^{\mathrm{n}}$ www.wassernet.at; ${ }^{\mathrm{o}}$ www.gismosel.lu; $\mathrm{p}$ Wanczura (2005); q Høydal et al. (2000) 
Switzerland, which can result in a wide variety in format and progress. For instance, in Germany and Poland different return periods are shown on the flood maps (Wanczura, 2005; Petrow et al., 2006), and in Spain and Italy there are many regions that are still uncharted (Cantos, 2005; Galderisi and Stanganelli, 2005; van Alphen and Passchier, 2007). In some countries national standards and guidelines have been established in order to avoid too much divergence in map formats (e.g. Switzerland and Finland).

Some countries have developed maps showing historical flood information. For example, Ireland has a nation-wide map showing the occurrence of historical floods and Flanders has a map with "recently flooded areas" (1988-2006) (D'Haeseleer et al., 2006). Flood extents of specific historical events are available in the Czech Republic (1997 and 2002 Elbe floods) and can be found for Finland and some French regions (van Alphen and Passchier, 2007).

The most common flood hazard maps are flood extent maps. Most flood extent maps depict flood extents for around three return periods. Different return periods are usually depicted using different colors/hues (e.g. Italy, Sweden, UK), by delineating the farthest extents as lines (e.g. Austria, Poland) or by a combination of both (e.g. Catalonia (Spain)). Very rarely, only one return period is calculated for the flood hazard (e.g. France), but sometimes only one return period is depicted per map while more are calculated (e.g. Norway). The most frequently used return period is $\mathrm{HQ}_{100}$ and the rarest event that is taken into consideration is $\mathrm{HQ}_{1000}$ (Flanders, UK, Hungary, Poland). In some countries an "extreme" flood is distinguished, which is not further specified. In Sweden the "extreme" flood is estimated to be close to $\mathrm{HQ}_{10000}$, which is equal to the highest European safety standard as implemented in the Netherlands.

Flood extent information can be supplemented by other information like flood depth, velocity (e.g. Austria and Sachsen, Germany) or information on the consequences of a flood. In Italy, flood extent and risk zones are depicted on the same map. Many maps use a topographic map or landuse information for the background of maps, thereby giving an indication of exposure on the same map. Few maps specifically show vital objects like hospitals and public utility services, as done in Sachsen (Germany).

Other flood parameters, like flood depth, velocity, or propagation, are also depicted on separate maps. In particular, flood depth is reported by many countries (e.g. Finland, Netherlands, Switzerland). Furthermore, combinations of several flood parameters (e.g. probability, depth, velocity) are used to develop flood danger maps, by using either a formula (e.g. UK) or a matrix (e.g. Wallonia, Switzerland: see Fig. 1).

Some countries have explicit exposure/coping capacity maps (e.g. UK, Italy, Romania), but only a few have combined hazard and exposure/coping capacity information into risk maps. France, Switzerland, and some regions in Spain and Italy have created qualitative risk maps, usually classified into three to five risk zones. France and the Span- ish and Italian regions use population, urban settlement, and infrastructure as indicators for exposure, and the Spanish and Italian regions also include some environmental indicators (Fleischhauer, 2005; Cantos, 2005; Galderisi and Stanganelli, 2005). Flanders and Sachsen (Germany) are the only regions where quantitative risk maps have been developed. Sachsen carried this out for the $\mathrm{HQ}_{\text {extr }}$ event, yielding damages in $€ /$ area (van Alphen and Passchier, 2007) where in Flanders damages were calculated for different probabilities and combined into damages in $€ /$ area/year (HIC, 2003).

\subsubsection{Use of flood maps by governments}

Flood maps are used for a variety of purposes by governments, mostly for emergency planning (e.g. evacuation) and spatial planning. In spatial planning a distinction can be made between countries where flood maps serve an advisory purpose, and countries where there is a binding legislation to use flood hazard or risk information. Flood zones (either extent or danger zones) can serve as an informative tool for decision makers (as in Norway and Sweden). In Finland and the UK, on the other hand, there is a legal obligation to consider flood zones in the planning process, but it cannot fully prohibit developments. In France, Poland, and recently Germany, there is a binding legislation with respect to restricting or prohibiting developments in flood-prone areas. However, binding legislation does not seem to guarantee effective flood risk management in practice. In Germany, effective flood risk management is hampered by the decentralised structure of the Bundesländer as many different entities (which can differ between Länder) have to cooperate and agree (Samuels et al., 2006). In France local authorities are tempted to underestimate hazard zones because the state will compensate the damage that can't be covered by the insurance (Fleischhauer, 2005). Furthermore, in Poland municipalities often do not follow regulations for financial reasons, even though law requires them to prohibit developments in the most floodprone zones (Wanczura, 2005). In Spain and Switzerland, regional governments can decide for themselves how strictly flood zones are incorporated into their spatial planning policies (Zimmerman et al., 2005; Cantos, 2005). In Switzerland, recommendations are made by the central government regarding flood zones, which are usually followed.

Besides the planning purposes, flood maps are also used to raise awareness about floods. In 12 of the countries considered flood maps are available online for the general public, sometimes combined with an option to search by address. In many cases this is part of a national campaign to prepare residents for floods (e.g. Ireland, UK). The use of historical flood information is particularly valuable in this respect as historical floods are not hypothetical events (like modelled ones), and can therefore be more easily understood by the general public. In Belgium, flood maps form the basis of an obligatory flood insurance scheme, in which higher premiums have to be paid in certain zones or coverage is allowed to be denied 
Table 2. Overview of flood maps produced by the insurance sector.

\begin{tabular}{|c|c|c|c|c|c|c|c|c|}
\hline \multirow[t]{2}{*}{ Name } & \multirow[t]{2}{*}{ Coverage } & \multicolumn{2}{|c|}{ Various } & \multicolumn{5}{|c|}{ Use } \\
\hline & & $\begin{array}{l}\text { * } \\
\text { ठ } \\
0 \\
0 \\
0 \\
0 \\
0 \\
0\end{array}$ & 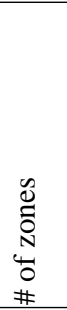 & 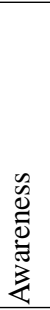 & 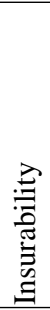 & 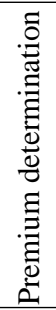 & 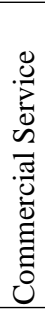 & $\begin{array}{l}0 \\
0 \\
0 \\
0 \\
0 \\
0 \\
0 \\
0 \\
0 \\
0 \\
0 \\
0\end{array}$ \\
\hline $\mathrm{HORA}^{\mathrm{a}}$ & Austria & PPP & 3 & $\mathrm{X}$ & & $X$ & & \\
\hline $\mathrm{ZURS}^{\mathrm{b}}$ & Germany & $\mathrm{N}$ & 4 & & $\mathrm{X}$ & & & \\
\hline $\mathrm{FRAT}^{\mathrm{c}, \mathrm{e}}$ & Czech Republic & $\mathrm{R} \& \mathrm{P}$ & $4-6$ & & & $X$ & & \\
\hline SIGRA $^{d}$ & Italy & $\mathrm{N}$ & 3 & & & $X$ & & \\
\hline CatNet $^{\mathrm{e}}$ & Belgium, Italy & $\mathrm{R}$ & 1 & & & & $\mathrm{X}$ & \\
\hline $\mathrm{CatNet}^{\mathrm{e}}$ & Czech Republic & $\mathrm{R}$ & 4 & & & & $\mathrm{X}$ & \\
\hline $\mathrm{CatNet}^{\mathrm{e}}$ & Germany & $\mathrm{R}$ & 3 & & & & $\mathrm{X}$ & \\
\hline $\mathrm{CatNet}^{\mathrm{e}}$ & Hungary & $\mathrm{R}$ & 3 & & & & $\mathrm{X}$ & \\
\hline $\mathrm{CatNet}^{\mathrm{e}}$ & Netherlands & $\mathrm{R}$ & 4 & & & & $\mathrm{X}$ & \\
\hline CatNet $^{\mathrm{e}}$ & Slovakia & $\mathrm{R}$ & 5 & & & & $\mathrm{X}$ & \\
\hline $\mathrm{CatNet}^{\mathrm{e}}$ & UK & $\mathrm{R}$ & 1 & & & & $\mathrm{X}$ & \\
\hline $\operatorname{RMS}^{\mathrm{f}}$ & UK, Bel, Ger & $\mathrm{R}$ & - & & & & & $\mathrm{X}$ \\
\hline EUROFLOODg & Ger, Fra, UK, Ita & $\mathrm{R}$ & - & & & & & $X$ \\
\hline
\end{tabular}

*N: national insurance association; R: re-insurance company; R-P: re-insurance company and private company; PPP: public private partnership. ${ }^{a}$ http://gis.lebensministerium.at/eHORA; ${ }^{b}$ Thieken et al. (2006); ${ }^{\mathrm{c}}$ http://www.intermap.com; ${ }^{\mathrm{d}}$ http://www.ania.it/sigra/index.asp; ${ }^{\mathrm{e}}$ Van Alphen and Passchier (2007); ${ }^{\mathrm{f}}$ RMS (2001, 2004); ${ }^{\mathrm{g}}$ EQECAT (2006).

(D'Haeseleer et al., 2006). Lastly, flood maps are also used frequently for water management purposes, in flood assessments, and to facilitate the insurance industry (see Sect. 3.2).

\subsection{Insurance industry}

In Britain the insurance industry is provided flood maps by the central government (Environment Agency) but many flood maps are also produced by the insurance industry itself (see e.g. CEA, 2005). Both national insurance associations, as well as re-insurance companies, have mapped flood hazards and risks in order to support their financial services (Table 2). Most maps created by the (re-)insurance are flood extent maps, depicting between one and six flood hazard zones.

The HORA project in Austria is a cooperation between the Austrian national insurance association and the Austrian government to jointly create national flood hazard maps. The Austrian government uses these maps to increase public awareness and they can be viewed in a WebGIS ${ }^{4}$ (whereas most other insurance related products are usually not publicly accessible), and the insurance companies use the maps to differentiate premiums between the different flood zones. In Germany, maps are produced by the German Insurance Association (ZÜRS project) in order to determine in which

\footnotetext{
${ }^{4}$ http://gis.lebensministerium.at/ehora
}

areas, or under which condition, buildings can be insured. In Italy, maps are also produced by the national insurance agency (ANIA), but there they are used to determine premiums by relating flood depth and velocity to damage potential (SIGRA project). In the Czech Republic, flood maps are also created to determine flood premiums. The FRAT system, created by a re-insurer and a GIS company, produces six hazard zones or four zones related to the tariff zones used by the national insurance association (CAP), and is used widely by the property insurance sector in the Czech Republic (van Alphen and Passchier, 2007).

CatNet is an interactive mapping tool created by a large re-insurance company and contains information about flood zones in many different European countries (but also outside Europe). The information in the system has different sources and the set as a whole is therefore quite heterogeneous. The tool is used as a commercial service to anyone who is interested. Maps for Belgium, Italy, the Czech Republic, and Slovakia, showing flood extents without taking into account flood protection measures, are created by the reinsurance company itself. For Hungary the $\mathrm{HQ}_{50}$ map was also produced by the re-insurance broker itself, but the other two zones $\left(\mathrm{HQ}_{100}\right.$ and $\left.\mathrm{HQ}_{1000}\right)$ were digitised from the official national maps made by the government. The maps for Germany were provided by German water institutes. For the 
Netherlands the safety standards are used as flood zones and for the UK only areas potentially affected by coastal floods are depicted (van Alphen and Passchier, 2007).

The RMS and EUROFLOOD models, both created by reinsurance companies, do not produce maps themselves, but calculate the insured damage corresponding to certain events using a stochastic precipitation dataset and a chain of hydrological and damage assessment models. As a result of this setup, these models not only take into account fluvial floods (like most other mapping efforts), but also floods caused by heavy rainfall exceeding the drainage capacity in flat areas. By calculating damages for several return periods, so-called probability-loss (P-L) curves can be created. Such curves are used by these re-insurance brokers to establish which probability corresponds to a certain loss so that reinsurance costs can adequately be assessed and financial solvency of the primary insurers can be guaranteed.

Flood hazard and risk data produced by the insurance sector is usually kept confidential. The available data on exposure and flood risk could, however, also be very valuable to emergency planners and water managers. These authorities in turn administer the hydrological data which is potentially of use to the insurers, providing a potential for mutually beneficial cooperation. Cooperation between the insurance industry and governments is also desirable when it comes to creating the flood maps themselves, as communication of flood hazards and risks is done by the government whilst insurance premiums are determined and collected by the insurers using their own information. As both actions concern the general public they should ideally be based on the same data.

There are some examples where governments and the insurance industry cooperate. In Austria the central government and the insurance sector explicitly worked together to create flood maps that are used for both awareness raising and premium determination. Furthermore, in both France and the UK the government disseminates its flood hazard information explicitly to the insurance companies, often adjusted to serve their specific needs. In France this is part of a flood insurance system whereby compulsory fees on all car and house insurances are collected to cover flood losses. This fund is administered by the insurance companies for which the state acts as a reinsurer in case of a large disaster (Fleischhauer, 2005).

\subsection{Trans-boundary maps}

Besides governments and the insurance sector there are some other producers of flood maps. The most noteworthy of these are transnational river basin authorities like the ICPR (Rhine), IKSE (Elbe), IKSO (Odra) and ICPDR (Danube). The ICPR was the first to create an atlas showing transboundary flood hazard information. The "Rhine-Atlas" features flood hazard maps showing the flood extent for $\mathrm{HQ}_{10}, \mathrm{HQ}_{100}$ and an extreme flood as well as four danger categories based on flood depth of the extreme flood. It also features flood risk maps showing five zones of potential damage and inhabitants affected (ICBR, 2001). Following the success of the RhineAtlas similar atlases have been made for the Elbe and Oder rivers within the framework of EU-INTERREG projects.

\section{Conclusions and recommendations}

There are many flood mapping activities in European countries and even though an effort has been made in this paper to compile as much information as possible it should not be considered wholly comprehensive. Most of the projects identified were initiated during the last one or two decades. In roughly half of the countries considered in this study these practices cover almost the entire territory, in a third of the countries considerable parts are covered, and in roughly a sixth of the countries there are very limited or no flood maps available. Even though there is a common conceptual framework to create flood hazard and risk maps, there exists a wide variety of methods. Especially the mapping of flood risks is broadly defined, as there are many different indicators for risk resulting from its broad definition (hazard times consequence).

Flood extent maps are the most commonly used flood maps, produced in about $80 \%$ of the countries considered. In eight of the countries considered, parameters other than flood extent are also taken into account, most commonly flood depth (in all eight), sometimes velocity (in Switzerland and Luxembourg), and very rarely propagation (to be developed in Hungary and Netherlands); even though this is important information for emergency planners. While some exposure (or coping capacity) data is often implicitly used (by using topographic maps as background) it is not often explicitly mapped (as is the case in Romania and the UK for example). Only very rarely is it combined with hazard information to create flood risk maps (e.g. Spain, Italy, Flanders). In most countries such maps are used for emergency planning, raising (public) awareness, and spatial planning. The full potential of regulating land use in flood-prone areas is often not reached because in many countries flood zones only serve as guidelines or there are practical problems related to the implementation of binding rules. In 12 European countries flood maps can be viewed online by the general public.

In the insurance sector flood extent maps are also frequently used. Insurance associations and reinsurance companies have created nationwide flood maps for different European countries. They use such maps mainly to determine insurability, to differentiate premiums, or as a commercial product. In some cases the wealth of information on insured assets is combined with sophisticated flood hazard data to calculate potential losses of flood events, enabling re-insurers to assess long-term financial solvability.

As most European countries already have some sort of flood map available and/or projects running, they already partly comply with the EU Flood Directive (2007/60/EC). 
However, most countries have yet to make the step from hazard to risk map. As risk has a broad definition, and methodologies to quantify it differ between countries, this could result in a wide variety of risk maps which will be difficult to compare. This could cause complications when it comes to setting up management plans as these are supposed to work at a basin scale, whereas the mapping is usually done by the individual countries. Early cross-boundary cooperation is therefore desirable in order to avoid comparability problems. A huge challenge remains for quantifying potential flood damages and incorporating indirect and nonmonetary damage (to nature, culture, etc.) in an appropriate and uniform way.

This review of flood mapping practices across 29 European countries also reveals some more general points when it comes to flood (risk) mapping. In many of the cases observed, the protective effect of flood defences is not incorporated in the mapping method or, when it is, the defences are considered not to fail. As flood defences are critical elements when it comes to flood hazards, it is important to properly deal with their effect and take into account the uncertainties surrounding their failure. Furthermore, none of the mapping projects have taken into account the effect of climate change on future flood hazards. Incorporating the effect of climate change as well as the surrounding uncertainties in flood risk management could be an important driver for spatial planners and investors for designing more sustainable housing and infrastructure in flood-prone areas.

Acknowledgements. The authors would like to thank the Dutch National research programme "Climate Changes Spatial Planning" for sponsoring this work and the EXCIMAP members for providing example maps and background information. Aline te Linde and Philip Ward are thanked for providing valuable comments on earlier versions of this manuscript. One anonymous reviewer, Pedro Restrepo and Attilio Castellarin are thanked for their constructive reviews.

Edited by: U. Ulbrich

Reviewed by: A. Castellarin, P. Restrepo, and another anonymous referee

\section{References}

Aerts, J. C. J. H., Renssen, H., Ward, P. J., de Moel, H., Odada, E., Bouwer, L. M., and Goosse, H.: Sensitivity of global river discharges under Holocene and future climate conditions, Geophys. Res. Lett., 33, L19401, doi:10.1029/2006GL027493, 2006.

ARMONIA: Report on the European scenario of technological and scientific standards reached in spatial planning versus natural risk management, ARMONIA Project, Deliverable 1.1, available at: www.eu-medin.org, 2005.

Büchele, B., Kreibich, H., Kron, A., Thieken, A., Ihringer, J., Oberle, P., Merz, B., and Nestmann, F.: Flood-risk mapping: contributions towards an enhanced assessment of extreme events and associated risks, Nat. Hazards Earth Syst. Sci., 6, 485-503,
2006,

http://www.nat-hazards-earth-syst-sci.net/6/485/2006/.

Burby, R. J.: Flood insurance and floodplain management: the US experience, Global Environmental Change Part B: Environmental Hazards, 3, 111-122, 2001.

Cantos, J. O.: Country Report - Spain, in: Report on the European Scenario of Technological and Scientific Standards reached in Spatial Planning versus Natural Risk Management, edited by: Greiving, S., Fleischhauer, M., and Wanczura, S., ARMONIA Project, Dortmund, 2005.

CEA: The insurance of natural events on European markets, Comité Européen des Assurances, Paris, AB 5050 (06/05), 2005.

CEA: Reducing the social and economic impact of climate change and natural catastrophes - insurance solutions and public-private partnerships, CEA, Brussels, Belgium, 2007.

D'Haeseleer, E., Vanneuville, W., Van Eerdenbruch, K., and Mostaert, F.: Gebruik van overstromingskaarten voor verschilende watergerelateerde beheers- en beleidsinstrumenten Water, September-Oktober 2006.

Dankers, R., Christensen, O. B., Feyen, L., Kalas, M., and De Roo, A.: Evaluation of very high-resolution climate model data for simulating flood hazards in the Upper Danube Basin, J. Hydrol., 347, 319-331, 2007.

de Moel, H. and Aerts, J. C. J. H.: Flood maps in Europe: a comparative evaluation of methods, availability and application, in: Proceedings of the 4th International Symposium on Flood Defence, Toronto, Canada, 6-5-2008, 28/1-11, 2008.

DKKV: Flood Risk Reduction in Germany - lessons learned from the 2002 disaster in the Elbe region, Deutsches Komitee für Katastrophenvorsorge e.V. (DKKV), Bonn, 29e, 2004.

Dubrovin, T., Keskisarja, V., Sane, M., and Silander, J.: Flood Management in Finland - introduction of a new information system, Nice, France, 2006.

EEA, WHO, and JRC: Impacts of Europe's changing climate - 2008 indicator-based assessment, European Environment Agency, Copenhagen, Denmark, EEA No 4/2008, available at: http: //reports.eea.europa.eu/eea_report_2008_4/en, 2008.

EQECAT: EuroFlood Brochure, available at: http://www.eqecat. com/resources/brochures/EuroFlood_May_15_2006.pdf, 2006.

EXCIMAP: Handbook on good practices for flood mapping in Europe, European exchange circle on flood mapping, available at: http://ec.europa.eu/environment/water/flood_risk/flood_atlas/ index.htm, 2007.

Fay, H. and Walker, G.: Country Report - UK, in: Report on the European Scenario of Technological and Scientific Standards reached in Spatial Planning versus Natural Risk Management, edited by: Greiving, S., Fleischhauer, M., and Wanczura, S., ARMONIA Project, Dortmund, 2005.

Fleischhauer, M.: Country Report - France, in: Report on the European Scenario of Technological and Scientific Standards reached in Spatial Planning versus Natural Risk Management, edited by: Greiving, S., Fleischhauer, M., and Wanczura, S., ARMONIA Project, Dortmund, 2005.

Galderisi, A. and Stanganelli, M.: Country Report - Italy, regional level, in: Report on the European Scenario of Technological and Scientific Standards reached in Spatial Planning versus Natural Risk Management, edited by: Greiving, S., Fleischhauer, M., and Wanczura, S., ARMONIA Project, Dortmund, 2005.

Greiving, S.: Country Report - Germany, in: Report on the Euro- 
pean Scenario of Technological and Scientific Standards reached in Spatial Planning versus Natural Risk Management, edited by: Greiving, S., Fleischhauer, M., and Wanczura, S., ARMONIA Project, Dortmund, 2005.

HIC: Wetenschappelijke onderbouw van de Vlaamse waterbeheersingsplannen, Hydrologisch Informatiecentrum, available at: http://www.lin.vlaanderen.be/awz/waterstanden/hydra/ publicaties/risico-brochure.pdf, 2003.

Hooijer, A., Klijn, F., Pedroli, G. B. M., and Van Os, A. G.: Towards sustainable flood risk management in the Rhine and Meuse river basins: Synopsis of the findings of IRMA-SPONGE, River Res. Appl., 20, 343-357, 2004.

Høydal, Ø. A., Berg, H., Haddeland, I., Petterson, L. E., Voks $\varnothing$, A., and Øydvin, E.: Procedures and Guidelines for Flood Inundation Maps in Norway, Potsdam, Germany, 252-261, 2000.

Hurkmans, R. T. W. L., de Moel, H., Aerts, J. C. J. H., and Troch, P. A.: Water balance versus land surface model in the simulation of Rhine river discharges, Water Resour. Res., 44, W01418, doi:10.1029/2007WR006168, 2008.

ICBR: Atlas van het overstromingsgevaar en mogelijke schade bij extreem hoogwater van de Rijn, Internationale Commissie ter Bescherming van de Rijn (ICBR), Koblenz, 2001.

Jelinek, R., Wood, M., and Hervas, J.: Risk Mapping of Flood Hazards in New Member States, EU Joint Research Centre, IPSC, NEDIES, EUR 22902, 2007.

Jonkman, S. N.: Loss of life estimation in flood risk assessment: theory and applications, PhD thesis, Delft University of Technology, 354 pp., 2007.

Jonkman, S. N., van Gelder, P. H. A. J. M., and Vrijling, J. K.: An overview of quantitative risk measures for loss of life and economic damage, J. Hazard. Mater., 99, 1-30, 2003.

Kleinen, T. and Petschel-Held, G.: Integrated assessment of changes in flooding probabilities due to climate change, Clim. Change, 81, 283-312, 2007.

Kron, W.: Keynote lecture: Flood risk = hazard $\mathrm{x}$ exposure $\mathrm{x}$ vulnerability, in: Flood Defence '2002, edited by: Wu, B., Wang, Z.-Y., Wang, G., Huang, G. G. H., Fang, H., and Huang, J., Science Press, New York, 2002.

Kundzewicz, Z. W., Mata, L. J., Arnell, N. W., Döll, P., Kabat, P., Jimenez, B., Miller, K. A., Oki, T., Sen, Z., and Shiklomanox, I. A.: Freshwater resources and their management, in: Climate change 2007: Impacts, Adaptation and Vulnerability. Contribution of Working Group II to the Fourth Assessment Report of the Intergovernmental Panel on Climate Change, edited by: Parry, M. L., Canziani, O. F., Palutikof, J. P., van der Linden, P. J., and Hanson, C. E., Cambridge University Press, Cambridge, UK, 2007.

Lavalle, C., Barredo, J. I., De Roo, A., Niemeyer, S., Miguel-Ayanz, J. S., Hiederer, R., Genovese, E., and Camia, A.: Towards an European integrated map of risk from weather driven events, European Commission - Joint Research Centre, EUR 22116 EN, available at: http://moland.jrc.it/documents/EUR_22116_2005_ Lavalle_et_al.pdf, 2005.

LDS NRW: Vorausberechnung der Bevölkerung 2005 bis 2025/2050 in NRW http://www.lds.nrw.de/statistik/ datenangebot/daten/a/r311prog.html, 2008.

Lucarini, V., Danihlik, R., Kriegerova, I., and Speranza, A.: Hydrological cycle in the Danube basin in present-day and XXII century simulations by IPCCAR4 global climate models, J. Geo- phys. Res.-Atmos., 113, D09107, doi:10.1029/2007JD009167, 2008.

Menoni, S.: Country Report - Italy, local level, in: Report on the European Scenario of Technological and Scientific Standards reached in Spatial Planning versus Natural Risk Management, edited by: Greiving, S., Fleischhauer, M., and Wanczura, S., ARMONIA Project, Dortmund, 2005.

Merz, R. and Bloschl, G.: Flood frequency regionalisation-spatial proximity vs. catchment attributes, J. Hydrol., 302, 283-306, 2005.

Merz, B., Kreibich, H., Thieken, A., and Schmidtke, R.: Estimation uncertainty of direct monetary flood damage to buildings, Nat. Hazards Earth Syst. Sci., 4, 153-163, 2004, http://www.nat-hazards-earth-syst-sci.net/4/153/2004/.

Merz, B., Thieken, A. H., and Gocht, M.: Flood risk mapping at the local scale: concepts and challanges, in: Flood Risk Management in Europe - innovation in policy and practice, edited by: Begum, S., Stive, M. J. F., and Hall, J. W., Springer, Dordrecht, Netherlands, 2007.

Merz, R., Blöschl, G., and Humer, G.: National flood discharge mapping in Austria, Natural Hazards, 46, 53-72, 2008.

Middelkoop, H., Daamen, K., Gellens, D., Grabs, W., Kwadijk, J. C. J., Lang, H., Parmet, B. W. A. H., Schädler, B., Schulla, J., and Wilke, K.: Impact of climate change on hydrological regimes and water resources management in the Rhine Basin, Clim. Change, 49, 105-128, 2001.

Milly, P. C. D., Wetherald, R. T., Dunne, K. A., and Delworth, T. L.: Increasing risk of great floods in a changing climate, Nature, 415, 514-517, 2002.

Munich RE: Weather catastrophes and climate change, Münchener Rückversicherungs-Gesellschaft, München, 2005.

Petrow, T., Thieken, A. H., Kreibich, H., Bahlburg, C. H., and Merz, B.: Improvements on flood alleviation in Germany: Lessons learned from the Elbe flood in August 2002, Environ. Manage., 38, 717-732, 2006.

RMS: RMS U.K. River Flood Model, Risk Management Solutions Inc., available at: http://www.rms.com/Publications/UK_River Flood.pdf, 2001.

RMS: RMS Belgium River Flood Model , Risk Management Solutions Inc., available at: http://www.rms.com/Publications/ BelgiumRiverFlood.pdf, 2004.

Roos, A. and Van der Geer, I.: New approaches for flood risk management in the Netherlands, in: Proceedings of the 4th International Symposium on Flood Defence, 6-8 May 2008, Toronto, Canada, 2008.

Roy, E., Rousselle, J., and Lacroix, J.: Flood Damage Reduction Program (FDRP) in Quebec: Case study of the Chaudiere River, Natural Hazards, 28, 387-405, 2003.

Samuels, P. and Gouldby, B.: Language of Risk - project definitions, FLOODsite Project, T32-04-01, available at: www.floodsite.net; www.eu-medin.org, 2005.

Samuels, P., Klijn, F., and Dijkman, J.: An analysis of the current practice of policies on river flood risk management in different countries, Irrigation and Drainage, 55, S141-S150, 2006.

Schmidt-Thomé, P., Kallio, H., Jarva, J., Tarvainen, T., Breiving, S., Fleischhauer, M., Peltonen, L., Kumpulainen, S., Olfert, A., Bärring, L., Persson, G., Relvao, A. M., and Batista, M. J.: The Spatial Effects and Management of Natural and Technological Hazards in Europe, ESPON 1.3.1, available at: www.espon.lu, 
2006.

te Linde, A. H., Aerts, J. C. J. H., and van den Hurk, B.: Effects of flood control measures and climate change in the Rhine basin, in: Proceedings of the 4th International Symposium on Flood Defence, Toronto, Canada, 6-5-2008, 118/1-9, 2008.

Thieken, A. H., Petrow, T., Kreibich, H., and Merz, B.: Insurability and mitigation of flood losses in private households in Germany, Risk Analysis, 26, 383-395, 2006.

Tunstall, S. M., Johnson, C. L., and Pennning Rowsell, E. C.: Flood Hazard Management in England and Wales: From Land Drainage to Flood Risk Management, in: Proceedings of the World Congress on natural Disaster Mitigation, New Delhi, India, 19-2-2004, 2004.

van Alphen, J., Martini, F., Loat, R., Slomp, R., and Passchier, R.: Flood risk mapping in Europe, experiences and best practices, in: Proceedings of the 4th International Symposium on Flood Defence, Toronto, Canada, 6-5-2008, 150/1-8, 2008.

van Alphen, J. and Passchier, R.: Atlas of Flood Maps, examples from 19 European countries, USA and Japen, Ministry of Transport, Public Works and Water Management, The Hague, Netherlands, prepared for EXCIMAP, available at: http://ec.europa.eu/ environment/water/flood_risk/flood_atlas/index.htm, 2007. van Alphen, J. and van Beek, E.: From flood defence to flood management - Prerequisites for sustainable flood management, in: Floods, from Defence to Management, edited by: van Alphen, J., van Beek, E., and Taal, M., Taylor \& Francis Group, London, 2006.

Vis, M., Klijn, F., De Bruijn, K. M., and van Buuren, M.: Resilience strategies for flood risk management in the Netherlands, International Journal of River Basin Management, 1, 33-39, 2003.

Wanczura, S.: Country Report - Poland, in: Report on the European Scenario of Technological and Scientific Standards reached in Spatial Planning versus Natural Risk Management, edited by: Greiving, S., Fleischhauer, M., and Wanczura, S., ARMONIA Project, Dortmund, 2005.

Watt, W. E.: Twenty Years of Flood Risk Mapping under the Canadian National Flood Damage Reduction Program, in: Flood Issues in Contemporary Water Management, edited by: Marsalek, J., Watt, W. A., Zeman, E., and Sieker, F., Kluwer Academic Publishers, 2000.

Zimmerman, M., Pozzi, A., and Stoessel, F.: Vademecum Hazard Maps and Related Instruments, The Swiss System and its Application Abroad, PLANAT, Bern, Switzerland, available at: http://162.23.39.120/dezaweb/ressources/resource_en_25123. pdf, 2005. 